\title{
On the storage of some fresh wild mushrooms
}

JUHA KOIVURINTA

\begin{abstract}
KOIVURINTA, J. 1978: On the storage of some fresh wild mushrooms. - Karstenia 18 (suppl.).
Mushrooms are usually considered as easily perishable products. Very little information is available in the literature on storage keepability of fresh wild mushrooms.

The possibilities of keeping fresh wild mushrooms in cold storages have been studied at the University of Helsinki, Department of Food Chemistry and Technology, using the crops of 1975 and 1976. Different packing materials and storage temperatures were used. Organoleptic methods were used to follow up quality changes in mushrooms. Some respiration measurements were also made.

The best packing material was polyethene. The storage time varied from some days to several weeks. Great differences were observed with different mushroom species.

J. Koivurinta, Department of Food Chemistry and Technology, University of Helsinki, SF-00710 Helsinki 71, Finland.
\end{abstract}

\section{Introduction}

The storage stability of mushrooms is usually considered to be poor. Numerous research papers have been published about the effect of different parameters such as storage temperature (Sveine et al. 1967), oxygen and carbon dioxide content of storage atmosphere (Murr \& Morris 1975 b), different packaging materials (Nicholas \& Hammond 1973, 1974, 1975, 1976, Sveine et al. 1967, Gormley \& MacCanna 1967), etc., on the storage of champignon (Agaricus bisporus). Usually lowering of storage temperature, lowering of oxygen content in storage room, using plastic films, and also using radiation increased the storage stability of the champignon. In all the papers mentioned storage stability has been measured by respiration intensity measurements. The respiration intensity of mushrooms is much higher than that of other materials of plant origin (Hammond \& Nichols 1975). This is believed to have a fundamental effect on the storage stability of mushrooms (Sveine et al. 1967, Lutz \& Hardenburg 1968, Ryall \& Lipton 1972). Darkening of the color and toughening of the structure have been observed (Murr \& Morris 1975 a, Goodenough 1976, MacCanna \& Gormley 1969) when storage experiments have been made with champignon.

Depending on the criteria used, different storage times have been reported for champignon. Very little information is available on the storage times of wild forest mushrooms.

The purpose of this study was to obtain a rough idea of how long different wild mushrooms growing in Finland could be stored fresh at different temperatures and in different packaging materials. Tests have been carried out from both 1975 and 1976 crops. Organoleptic as well as some respiration measurements were used to describe spoilage.

\section{Materials and methods}

Several mushroom species were used (Table 1), but because of lack of fresh material complete testing was not possible with every species. All the material was picked by the research staff and the experiments were initiated within 6-8 hours from picking. If this was not possible the mushrooms were stored at $4^{\circ} \mathrm{C}$. (Some fresh mushrooms were bought from commercial sources and the exact time of picking was not known). The mushrooms were cleaned according to normal commercial practice before use.

Three packaging materials were used: aluminium foil, polyethene ( $L D, 0.03 \mathrm{~mm}$ ) and paper (imitating unpacked material). For each package $100 \mathrm{~g}$ of sample was used. Aluminium foil was not used in the 1976 experiment's.

The mushrooms were stored at three different temperatures: $+4,+10$, and $+20^{\circ} \mathrm{C}$. Temperature $20^{\circ} \mathrm{C}$ was not used in the 1976 experiments. Organoleptic analysis was conducted at different intervals.

Table 1. Mushroom species used in the study. Mushrooms were cleaned according to normal commercial practice before use.

\begin{tabular}{lccc}
\hline \multicolumn{1}{c}{ Mushroom species used } & $\begin{array}{c}\text { Crop of } \\
1975\end{array}$ & $\begin{array}{c}\text { Crop of } \\
1976\end{array}$ & Comments \\
\hline Lactarius trivialis & $\mathrm{x}$ & $\mathrm{x}$ & \\
Lactarius mufus I & $\mathrm{x}$ & $\mathrm{x}$ & Rainy weather \\
Lactarius mufus II & & $\mathrm{x}$ & Dry weather \\
Cantharellus cibarius & & $\mathrm{x}$ & \\
Tricholoma flavovirens & & $\mathrm{x}$ & \\
Tricholoma portentosum & & $\mathrm{x}$ & \\
Armillariella mellea & & $\mathrm{x}$ & \\
Hydnum mifescens & & $\mathrm{x}$ & \\
Agaricus bisporus & & $\times$ & As reference \\
\hline
\end{tabular}


In organoleptic measurements a scoring method (Amerine et al. 1965) was used. A verbal scale ranging from excellent to bad was given to panelists and changed into numbers (5-1) for analysing the results. Colour, smell, texture and taste were analysed separately. As discussed above, both colour and texture of the champignon changes during storage. Fresh control samples were not available at each testing. Taste was analysed after boiling the mushrooms for 5 min at $1.5 \% \mathrm{NaCl}$ solution using mushroom to water ratio of $1: 9$. An expert panel of 6 persons was used, all members belonging to the laboratory staff.Samples were considered spoiled when at least one of the properties judged received scores below or equal to 2.0 (slightly bad).

Respiration was measured with a Warburg manometer (Umbreit et al. 1957, Rast 1961, Hou \& Wu 1972) using $0.02 \mathrm{M} \mathrm{KH}_{2} \mathrm{PO}_{4}$ solution (Ap Rees \& Bryant 1971).
Before measurements the mushrooms were cleaned an the gills were removed from Lactarius, Armilzariella, Tricholoma and Cantharellus. Two to four mushrooms were sliced to $0.5 \mathrm{~mm}$ slices. Round $\emptyset 6 \mathrm{~mm}$ pieces were cut and $0.125-0.500 \mathrm{~g}$ of these pieces were weighed for each measurement so that half of the pieces were from tire cap and the rest from the foot. Both oxygen consumption and carbon dioxide production were measured and calculated to the fresh weight. Oxygen consumption was also calculated to the volume and area of the sample (Kovacs \& Vas 1974 b). The $R Q$ value was calculated by dividing the amount of $\mathrm{CO}_{2}$ released by the amount of $\mathrm{O}_{2}$ consumed.

\section{Results and discussion}

Storage times of different mushroom species can be seen in Table 2 together with the limiting property.

Table 2. Storage time of different mushroom species at $+4^{\circ} \mathrm{C}$.

\begin{tabular}{|c|c|c|c|c|c|}
\hline \multirow[t]{2}{*}{ Mushroom species } & \multirow{2}{*}{$\begin{array}{l}\text { Packaging } \\
\text { material }\end{array}$} & \multirow{2}{*}{$\begin{array}{c}\frac{\text { Storage }}{\text { crop }} \\
1976\end{array}$} & \multirow{2}{*}{$\frac{\text { time, days }}{\text { of } \quad 1975}$} & \multicolumn{2}{|l|}{$\begin{array}{l}\text { Limiting } \\
\text { property }\end{array}$} \\
\hline & & & & 1976 & 1975 \\
\hline \multirow[t]{3}{*}{ Lactarius trivialis } & Paper & 19 & 15 & Taste & Colour \\
\hline & Polyethene & 27 & $16(12)$ & ) Smell. & Smell \\
\hline & Al-foil & - & 8 & - & Texture \\
\hline \multirow[t]{3}{*}{ Lactarius mufus $I$} & Paper & 22 & 9 & Texture & Texture \\
\hline & Polyethene & 45 & $>23$ & Taste & - \\
\hline & Al-foil & - & 7 & - & \\
\hline \multirow[t]{3}{*}{ Lactarius mufus II } & Paper & 23 & - & Texture & \\
\hline & Polyethene & 39 & - & Taste & \\
\hline & Al-foil & - & - & - & \\
\hline \multirow[t]{3}{*}{ Contharellus cibarius } & Paper & 24 & & Texture & \\
\hline & Polyethene & 95 & - & Taste & \\
\hline & Al-foil & - & - & - & \\
\hline \multirow[t]{2}{*}{ Agaricus bispomis } & Paper & 20 & - & Texture & \\
\hline & Polyethene & 24 & - & Smell & \\
\hline
\end{tabular}

Storage time of different mushroom species at $+10^{\circ} \mathrm{C}$.

\begin{tabular}{|c|c|c|c|c|c|}
\hline \multirow[t]{2}{*}{ Mushroom species } & \multirow[t]{2}{*}{$\begin{array}{l}\text { Packaging } \\
\text { material }\end{array}$} & \multicolumn{2}{|c|}{$\frac{\text { Storage time, days }}{\text { crop of }}$} & \multicolumn{2}{|c|}{ - Limiting } \\
\hline & & 1976 & 1975 & 1976 & 1975 \\
\hline \multirow[t]{3}{*}{ Lactarius trivialis } & Paper & 21 & 10 & Taste & Smell \\
\hline & Polyethene & 27 & 15 & Taste & \\
\hline & Al-foil & - & 5 & - & Taste \\
\hline \multirow[t]{3}{*}{ Lactarius mufus I } & Paper & 22 & 9 & Texture & Taste \\
\hline & Polyethene & 32 & $>23$ & Smell & \\
\hline & Al-foil & - & 2 & - & \\
\hline \multirow[t]{3}{*}{ Lactarius rufus II } & Paper & 26 & - & Texture & \\
\hline & Poly ethene & 33 & - & Smell & \\
\hline & Al-foil & - & - & - & \\
\hline \multirow[t]{3}{*}{ Contharellus cibarius } & Paper & 42 & - & Texture & \\
\hline & Polyethene & 100 & - & Taste & \\
\hline & Al-foil & - & - & - & \\
\hline \multirow[t]{2}{*}{ Agaricus bisporus } & Paper & 18 & - & Taste & \\
\hline & Polyethene & 18 & - & Taste & \\
\hline
\end{tabular}


The storage times of the wild mushrooms studied differed very little at the different storage temperatures tested, in contrast to the champignon which had a considerably longer storage time at $+4^{\circ} \mathrm{C}$ than at $10^{\circ} \mathrm{C}$. Similar results have been published earlier (Dredge 1964, Hughes 1959, Gormley 1975). Wild mushrooms had longer storage times than champignon.Polyethene was by far the best packaging material out of the three used. The packaging material seems to affect the storage time more than the temperature. The limiting property of mushrooms packed in paper bags was in most cases structure. This is most probably due to the drying of mushrooms during storage. In polyethene bags the limiting property was smell or taste. This is most probably due to the high humidity in the bag (Gormley \& MacCanna 1967). Colour does not seem to be very important, perhaps because of the dark colours and the great differences in colour of fresh mushrooms. Aluminium foil proved not to be applicable for the packing of mushrooms. The purpose was to measure the respiration of all mushrooms used in the storage experiments but problems in the respiration measurements delayed the experiments so much that fresh material was no longer available(Table 3),

Table 3. RQ values of mushrooms.

\begin{tabular}{ll}
\hline Mushroom species & $\mathrm{RQ}$ \\
\hline Cantharelzus cibarius & 0.54 \\
Tricholoma flavovirens & 0.81 \\
Armilzariella melzea & 0.78 \\
Hydnum rufescens & 0.42 \\
Agaricus bisporus & 0.76 \\
\hline
\end{tabular}

Cantharellus cibarius has a very low $\mathrm{RQ}$ value and good storage stability. The $R Q$ of Agaricus bisporus is comparable to the results of Hou \& Wu (1972); other values have been registered with different methods (Kovács \& Vas 1974 a). The cutting of mushrooms used in our experiments increases the respiration rate (Appleman \& Brown 1946, Laties 1957, Hruschka 1967). Also the removal of gills affects the results because the respiration rate is greatest at the gills.

\section{References}

Amerine, M.A., Pangborn, R.M. \& Roessler, E.B. 1965: Principles of sensory evaluation of food. 422 p. New York.

Ap Rees, T. \& Bryant, J.A. 1971: Effects of cycloheximide on protein synthesis and respiration in disks of carrot storage tissue. - Phytochemistry 10: 1183-1190.

Appleman, C.O. \& Brown, R.G. 1946: Relation of anzerobic to aerobic respiration in some storage organs with special reference to Pasteur effect in higher plants. - Am. J. Bot. 33: 170-181.
Dredge, A.L.A. 1964: Prolongation of the shelf life of mushrooms by cold storage. - Mushroom Growers Assoc. Bull. No. 172: 146-150:

Goodenough, P. W. 1976: How chilled storage affects the physiology of mushrooms. - Mushr. J. No. 43: 208-212.

Gormley, R. 1975: Chill storage of mushrooms. - J. Sci. Food Agric. 26: 401-411.

Gormley, R. \& MacCanna, C. 1967: Prepacking and shelf life of mushrooms. - Ir. J. Agric. Res. 6: 255265.

Hammond, J.B. W. \& Nichols, R. 1975: Changes in respiration and soluble carbohydrates during the post -harvest storage of mushrooms (Agaricus bisporus). - J. Sci. Food Agric. 26: 835-842.

Hou, H-H. \& Wu, L-C. 1972: Respiratory changes in the cultivated mushroom, Agaricus bisporus. Mushr. Sci. 8: 399-411.

Hruschka, H.W. 1967: Storage and shelf life of packaged rhubarb. Respiration measurements. Marketing Research Report No. 771. Agricultural Research Service. U.S. Dept. Agric.,Washington, D.C.

Hughes, D.H. 1959: Mushroom discoloration research at the university of Delaware. - Mushr. Sci. 4: 447-449.

Kovács, E. \& Vas, K. 1974a: Effect of ionizing radiation on post-harvest ripening processes of cultured mushrooms (Agaricus bisporus), with special reference to the rates of respiration and ethylene production. - Acta Alimentaria 3: $19-25$.

-"- 1974b: Methodological studies on the determination of respiration and ethylene production of fruits and vegetables. - Acta Alimentaria 3: $1-9$.

Laties, G.G. 1957: Respiration and cellular work and the regulation of the respiration rate in plants. - Survey Biol. Prog. 3: 215-299.

Lutz, J.M. \& Hardenburg, R.E. 1968: The commercial storage of fruits, vegetables and florist's and nursery stock. - Agriculture Handbook No. 66. U.S. Dept. Agric., Washington, D.C.

MacCanna, C. \& Gormley, T.R. 1969: Quality assessment of mushrooms: relationship between moisture loss, colour and toughness of harvested cultivated mushrooms. - Mushr. Sci. 7: 485492.

Murr, D.P. \& Morris, L.L. 1975a: Effect of storage temperature on postharvest changes in mushrooms. - J. Am. Soc. Hort. Sci. 100: 16-19.

-" 1975b: Effect of storage atmosphere on postharvest growth of mushrooms. - J. Am. Soc. Hort. Sci. 100: 298-301.

Nichols, R. \& Hammond, J.B.W. 1973: Storage of mushrooms in pre-packs: the effect of changes in carbon dioxide and oxygen on quality. - J. Sci. Food Agric. 24: 1371-1381.

-" - 1974: Investigations on storage of pre-packed mushrooms.-Mushr. J. 4: 473-479. 
-"- 1975: The relationship between respiration, atmosphere and quality in intact and perforated mushroom pre-packs. - J. Food Technol. 10: 427-435.

-" 1976: Storage of Agaricus edulis (syn. A. bitorquis) sporophores in pre-packs. - Mushr. J. 45: $286-288$.

Rast, D. 1961: Atmungsmechanismen des Kulturchampignons (Agaricus campester). Ber. Schweiz. Bot. Ges. 71: 209-301.
Ryall, A.L. \& Lipton, W.J. 1972: Handling, Transportation and Storage of Fruits and Vegetables. - 473 p. Westport, Connecticut.

Sveine, E., Klougart, A. \& Rasmussen, C.R. 1967: Ways of pro-longing the shelf-life of fresh mushrooms. - Mushr. Sci. 6: 463-474.

Umbreit, W.W., Burris, R.H. \& Stauffer, J.F. 1957: Manometric Techniques. 3rd Ed. -338 p. Minneapolis. 